\title{
Influence of Rational and Emotional Appeals on Purchasing Through Online: The Case on Social Media
}

\author{
Mohammad Toufiqur Rahman ${ }^{1} \&$ Tanjina Pial ${ }^{1}$ \\ ${ }^{1}$ Department of Business Administration, International Islamic University Chittagong, Bangladesh \\ Correspondence: Mohammad Toufiqur Rahman, Assistant Professor, Department of Business Administration, \\ International Islamic University Chittagong, Bangladesh. Tel: 88-0171-1900-667.
}

Received: September 11, 2019

Accepted: October 7, $2019 \quad$ Online Published: October 16, 2019

doi:10.5430/ijfr.v11n1p34

URL: https://doi.org/10.5430/ijfr.v11n1p34

\begin{abstract}
Advertising appeals is a powerful process for companies to influence customers' buying decisions. The primary aim of this research is to figure out that every customer has the same impact on all advertising appeal or not and what sort of promotional appeal can be more easily and efficiently applied to consumers. To get the answer, the information was gathered by organized questionnaires from 82 people randomly in various regions in Bangladesh, who frequently do online purchase through social media, between April and July 2019. The research shows that most of the customers are influenced by both emotional and rational advertising appeals. From t-test it has been observed that both males and females are influenced by the same way whether the advertising positioning is rational or emotional. It has also been observed that all categories customers are influenced more by those emotional advertisements that depict sociality and in rational positioning, all are influenced that demonstrating the product uses, benefits and features. The age group 'less than 30 years' and the 'students' are more influenced by emotional than from rational appeals.
\end{abstract}

Keywords: emotional positioning, rational positioning, appeal, influence, purchasing

\section{Introduction}

Artwork, images, and expressions are utilized for displaying the product to attract consumer attention and make customers pick their product among other products on the market that are accessible. Organizations spend a big portion of their budget to create and manage advertisements for promotions to impart data about their organization and items. They reach big numbers of people with a broad variety of cultural and ethnic backgrounds through television, radio and the internet.

In research by Philip Kotler (2007) identified that the theme of an advertisement appeal is advertising, which adds some driving force in the advertisements to make the public obtain needed messages and generate interest in Ads. That driving force is an appeal. Each advertising appeal is an attraction that triggered the desires of consumers. Customers uncovered a variety of advertising appeals in daily experiences. The aim of these appeals is to influence the attitudes of customers towards a variety of goods and services. Advertising appeals are a reflection of convincing psychological effects and serve as important indicators to evaluate publicity efficiencies. Kotler and Keller (2003) isolated advertising appeal into two sections which were known as rational and emotional appeals.

Customers are bound to connect with ads of those brands that contain emotional and rational messages and beliefs. Rational and Emotional appeals give the brand a powerful indication as well as promote category-based processing. In an advertisement, advertisers use distinct appeals that emotionally awaken the viewer that leads to a product purchase intent. The selection of the right advertising appeal turns out to be crucially significant when effective promotional campaigns are being established. For epicurean items, emotional appeals are applicable, while for utilitarian items rational appeals are important identified by Authors (Armstrong, 2010; Lantos, 2015). The rational appeal is intended to highlight the distinctive characteristics and advantages of the products in order to prove the value of the specific brand owned or used. 


\section{Literature Review}

Advertising is a non-individual display and advertising of thoughts, products or facilities by a paying advertiser (Kotler, 2007). The attitude of the individual behavior, lifestyle, and culture of the country can be affected by advertising on a long-term basis (Latif, \& Abideen, 2011).

Advertising is frequently viewed as either rational or emotional within a framework that identifies advertising appeals (Solomon, 1992). In two ways, the public perceives Advertising, a logical sense and a passionate one. This is the reason the majority of ads are categorized as "logical" ads, and "emotional" ads (Zhang, Sun, Liu, \& G. Knight, 2014). Sadeghi, Fakharyan, Dadkhah, Khodadadian, Vosta, and Jafari, (2015) explained in detail that the advertising attitude may have two parts: cognitive and affective (emotionally based) attitudes. Therefore, customer behavior can be determined by rational, emotional or both appeals.

Some studies investigated the rational and emotional effectiveness of advertising (e.g. Johar, \& Sirgy, 1991; Stafford, 2005). The word "emotion" is regarded to be personal, a knowledgeable practice characterized fundamentally by psychiatric phrases, biological responses, and a psychiatric condition. Both positive and negative emotions can exist. People often show their emotions by their sentiments, states of mind and affections. In marketing, it is commonly accepted that emotion stimulates the intention to buy (Xie, Donthu, Lohtia, \& Osmonbekov, 2004) and emotional content always increases the reminder of good-performing commercials (Roozen, \& Claeys, 2009). That is the reason advertisers depend on strongly contented emotional appeals to get their prospects energized, terrified, or excited. The emotional content of advertising contributes to convincing customers to the promoted brand, and how this will affect its intention to purchase (Niazi, Ghani, \& Aziz, 2012). Advertisers may use a number of emotional appeals, such as mood, pleasure, happiness as well as appeals like anxiety and guilt (Kotler, \& Armstrong, 2012). Keshari and Jain (2014) explained Emotional appeal as an attempt to convey adverse or beneficial feelings that can be motivating buying purchase of products. The primary negative emotions were guilt, dread, and disgrace (Keshari, \& Jain, 2014). Panda and Mishra (2013) stated that good feelings and positive consumer associations with advertised brands can arise from publicity based on positive emotions.

Rational appeals emphasize actualities, the rationale of influence and learning (Belch, G. E, \& Belch, M. A., 2012). Informative or logical appeals are also referred to as rational appeals in advertising, as they are utilized by advertisers to provide rational purposes for buying an advertised item (Sharma \& Singh, 2006). Rationally appealing advertisements emphasize the quality, worth, effectiveness or performance of the promoted item, along with the practical advantages and specific benefits shoppers would have in case they decided to use the selected item (Kotler \& Armstrong, 2012). In advertising, rational appeals can be categorized into one of the following classifications: function appeal, competitive advantage appeal, ideal cost advantage appeal, media appeal and appeal for brand awareness (Belch, G. E., \& Belch, M. A., 2004; Kazmi, \& Batra, 2009). Rizwan, Pirzada, Sohail, Nadeem, and Murid (2013) demonstrated that rational advertising has more impact than emotional advertising appeal on the favorable behavior of customers towards advertising. Emotional information-oriented appeals, as contrary to rational appeals, are fascinating, eye-catching. The latter appeal has been unsuccessfully considered as advertising cannot be effective if not understood (Belch, G E., \& Belch, M. A., 2004). Sadeghi et al. (2015) have stated that explicit product information that is characteristic of rational appeal ads contributes to a better advertising approach. Marketers use different advertising appeals, for example, rational and logical, to communicate data to users and to achieve the required marketing firm goals and objectives (Wang, Qiu, Kim, \& Benbasat, 2016).

The majority of ads are classified as thinking (coherent) promotions and feeling (emotional) advertisements (Zhang et al., 2014). Sadeghi et al. (2015) stated that although emotional appeals are much stronger, rational appeals are more important, giving clear item related data, so that rational appeals capture more exposure from customers. A growing number of promotional literature were concentrated on the different types of promoting appeals: rational vs. emotional (Li, H., Li, A., \& Zhao, 2009; Wang, \& Benbasat, 2008).

Now a day these rational and emotional appeals are now reflected through social media. A fresh area of communication called social media has been developed by the rapid development of the Internet. Social media is an internet network in which people exchange their idea, interface, data and concepts with people of similar minds (Taskiran, \& Yilmaz, 2015). Social media changes how people use the information and their lifestyle (Yu-Ting Ting 2013). New technologies have become accessible for the company through advances in the internet in recent years: social media, for instance, online societies being a great illustration (Lu, Y., Zhao, L., \& Wang, 2010). Overall internet access has allowed people to use social media, and to communicate via email, Twitter and Facebook, without the requirement for physical encounters (Gruzd, Wellman, \&Takhteyev, 2011). Social media provide a wide range of characteristics for companies, including encouraging word-of-mouth communication (Chen, Fay, \& Wang, 
2011); information-sharing in a company environment (Lu, \& Hsiao, 2010); improved brand recognition (De Vries, Gensler, \&Leeflang, 2012), increased revenues (Agnihotri, Kothandaraman, Kashyap, \& Singh, 2012) and producing social support for customers (Ali, 2011 ; Ballantine, \& Stephenson, 2011). The development of social media and SNSs is a research topic nowadays since social media will probably create marketing strategies for businesses via confidence-building systems and affect the desire of clients to purchase goods online (Liang, \& Turban, 2011).

\section{Objectives}

From the above discussion, we have sorted out some questions which need to be analyzed. Does every customer have the same impact on all advertising appeal? What sort of promotional appeal can be more easily and efficiently applied to consumers? This paper will try to analyze these questions and the objectives of this research are-

$\checkmark \quad$ To know both advertising appeals and their influences over customers.

$\checkmark \quad$ To know at what extent males and females are influenced by both advertising appeals.

$\checkmark$ To know which emotional and rational appeal characteristics influence more on different age groups, professions, and education.

\section{Methodology}

This study has relied on the questionnaire survey method. Albers-Miller, and Royne Stafford (1999); Moriarty. (1991); Belch et al. (2012); Keshari, and Jain (2014) identified several types of emotional and rational advertising appeals. Their identified keywords and the questionnaire of Khanna (2016) have been adapted for this study to identify the influence of rational and emotional appeals on purchasing online in Bangladesh. The questionnaire has been divided into two parts. The first part contains the information regarding the respondents and the second part contains how consumers' influence towards rational and emotional appeal on purchasing online. In each statement, on a five-point Likert scale, respondents are asked to indicate their level of understanding. In order to evaluate whether the questionnaire was valid, the author questioned a board of five specialists comprising two academicians, two researchers, and a professor. After the first draft, the questionnaire was revised according to their suggestions.

Some rational appeal characteristics are, like goods/service quality, functionality, economy, reliability, adequacy, effectiveness, competitiveness, wellbeing, sustainability, proficiency, low price, comfort and fame (Belch et al., 2012).

Energy, anxiety (threat, individual humiliation), family (adore, assurance), blame, cherish (fondness, sentiment), sentimentality, delight (funniness, bliss, and pleasure), strength, pride, help, and distress (pain, enduring) are specified by Moriarty (1991) as emotional appeals. In expansion, Hoyer and MacInnis (2001) mentioned that emotional appeal generates emotions such as affection, desire, happiness, desire, enthusiasm, brave, dread, rage, disgrace or refusal (Verma, 2009).

Keshari et al. (2014) asserted that if the advertisement contained any one of the information: value for item or service, feature, content, buying moment and location, any information on the product's research, bundling than it may be regarded as rational appeal advertising. On the other hand, If the advertisement does not include any of the above, it is considered to be an emotional appeal ad.

\subsection{Research Design}

A quantitative research approach has been used to analyze how emotional and rational publicity appeals affect online shopping, learned how advertising appeals in different ways influence various professionals, how various kinds of advertising appeals influence gender and how different kinds of advertisement appeals affect different elderly.

\subsection{Data Collection Method}

The survey has been conducted to obtain knowledge into the influence of rational and emotional appeal on purchasing online. Data were gathered from a survey questionnaire of people of Chattoram City who do online purchases through social media of low-involvement products from various regions of Bangladesh for their daily use. The questionnaire consists of close-ended simple questions regarding the key points of influence of rational and emotional appeal on purchasing in social media. Close-questions are the profession, gender, age, education. While filling in the list of questions concerning Sociality advertising appeal, Relaxation, Family Intimacy, Adventure, Pleasure, Beauty ,Effectiveness, Convenience, Health, Cheapness, Safety and Productivity, respondents were asked to rate them from strongly agree to strongly disagree. The scale used in this research form has been made by the Likert scale, which has five levels: from strongly disagree to strongly agree (1- strongly agree, 5 -strongly disagree). There are 12 questions about the influence of rational and emotional appeal on purchasing through online listed in the questionnaires. 
The population designed for this study was limited to the people of the Chattogram City of Bangladesh. To conduct this research, we had chosen Facebook as social media. The sample consisted of 82 interviewees from April 2019 to July 2019 at the separate sites in the town of Chattogram. A simple random sampling was used to obtain a relatively precise population cross-section and to make the findings pure. It was organized and analyzed after the data was collected. A computer programmed, the Statistical Package for Social Sciences (SPSS), was used for the analysis of closed-ended questions.

\subsection{Analysis}

\subsubsection{Reliability Analysis}

Table 1. Reliability analysis

\begin{tabular}{ll}
\hline Reliability Statistics & \\
\hline Cronbach's Alpha & Number of Items \\
\hline .740 & 12 \\
\hline
\end{tabular}

Reliability is analyzed to measure the adequacy of the internal consistency based on Cronbach's Alpha $(\alpha)$ coefficient. The scale for the item is considered to be reliable if the value of $\alpha$ is 0.70 or above (Hair, Black, Babin \& Anderson, 2009). Therefore, we can conclude that the inner coherence of the object scale is credible for this research.

4.3.2 Descriptive Analysis

Table 2. Descriptive analysis

\begin{tabular}{llllll}
\hline \multirow{4}{*}{ Profession } & Frequency & Percent & Valid Percent & Cumulative Percent \\
\hline & Service holder & 50 & 61.0 & 61.0 & 61.0 \\
\cline { 2 - 6 } & Business man & 10 & 12.2 & 12.2 & 73.2 \\
\cline { 2 - 6 } House wife & 14 & 17.1 & 17.1 & 90.2 \\
\cline { 2 - 6 } Gender & Student & 8 & 9.8 & 9.8 & 100.0 \\
\hline \multirow{3}{*}{ Age Group } & Male & 52 & 63.4 & 63.4 & 63.4 \\
\cline { 2 - 6 } & Female & 30 & 36.6 & 36.6 & 100.0 \\
\hline \multirow{3}{*}{ Education } & Less than 30 & 28 & 34.1 & 34.1 & 34.1 \\
\cline { 2 - 6 } & 30-45 & 49 & 59.8 & 59.8 & 93.9 \\
\cline { 2 - 6 } & 46-61 & 5 & 6.1 & 6.1 & 100.0 \\
\cline { 2 - 6 } & HSC & 5 & 6.1 & 6.1 & 6.1 \\
\cline { 2 - 6 } & Machelor's degree & 24 & 29.3 & 29.3 & 35.4 \\
\hline & Total & 82 & 100.0 & 100.0 & 100.0 \\
\hline
\end{tabular}

Table 2 shows the real figure of the profession, gender, age, and education level, who were participating in the questionnaire survey. The highest number of participants in the "profession" category was $61 \%$ of the Service Holder Group and the remaining 39\% included businessmen, housewives, and Students. In gender cases, we got maximum of our sample male respondents that was $63.4 \%$, and $36.6 \%$ of respondents were female. The figure also indicates the respondent's age. The largest part influenced in our random sampling by advertisements appeals was between 30 and 45 years $(59.8 \%)$. The highest participants were among this age bracket because middle-aged individuals are the destination audience for Fast Moving Consumer Goods (FMCG) brands, who give the highest attention to advertising. Along with this large proportion of participants are also attracted to the advertisements whose ages were less than 30 years of age (34.1\%). The remaining $6.1 \%$ belonged to the age group of $46-61$ years of age. The above 
figure also depicts that the number of respondents was higher at educational level. The largest group of respondents which contains $64.6 \%$ was the master's degree, while the other group was the bachelor's degree (29.3\%) and the rest group was HSC (6.1\%).

\subsubsection{Mean Value Analysis}

Table 3. Mean value

\begin{tabular}{llll}
\hline Emotional appeal & Valid & Missing & Mean \\
\hline Emotional appeal depicting social status like the presence of celebrity in the ads & 82 & 0 & 1.70 \\
\hline Emotional appeal-like good music for the creation of mood and emotions & 82 & 0 & 2.80 \\
\hline An emotional appeal that contains intimacy of family. & 82 & 0 & 2.36 \\
\hline Emotional appeal depicting the use of adventure/action and thrilling scene. & 82 & 0 & 3.17 \\
\hline $\begin{array}{l}\text { Emotional appeal demonstrating fun and happiness to induce smiles and laughter } \\
\text { in the ads. }\end{array}$ & 02 & 2.41 \\
\hline $\begin{array}{l}\text { Emotional appeal demonstrating the presence of striking scenes of nature scenes, } \\
\text { (Mountains, flowing streams, etc.) }\end{array}$ & 82 & 0 \\
\hline Rational Appeal & 82 & 0 & 2.53 \\
\hline Rational appeal demonstrating product use, benefits, and product features. & 82 & 0 & 1.68 \\
\hline Rational appeal using context/premium tie in ads. & 82 & 0 \\
\hline Rational appeal depicting taste, health and nutrients claims in the product & 82 & 0 \\
\hline Rational appeal demonstrating economy and savings in the purchase of a product. & 82 & 2.75 \\
\hline Rational appeal demonstrating safety by using a product. & 82 & 0 \\
\hline Rational appeal demonstrating productivity & 0 & 2.73 \\
\hline
\end{tabular}

The above table demonstrates the mean of the 82 reactions of individuals. In this table, majority of the variables have an average value of about 2 or mildly higher than 2 , indicating that the impact of the emotional or rational advertising appeal on these appeal components is agreed by most individuals.

\subsubsection{T-Test}

Table 4. T-Test

\begin{tabular}{|c|c|c|c|c|}
\hline & Gender & $\mathbf{N}$ & Mean & Std. Deviation 2-tailed Prob \\
\hline \multirow[t]{2}{*}{ Sociality } & Male & 52 & 1.7115 & .89303 \\
\hline & Female & 30 & 1.7000 & .65126 \\
\hline \multirow[t]{2}{*}{ Relaxation } & Male & 52 & 2.8269 & -.804 \\
\hline & Female & 30 & 2.7667 & 1.10433 \\
\hline \multirow[t]{2}{*}{ Family Intimacy } & Male & 52 & 2.3654 & .79283 \\
\hline & $\overline{\text { Female }}$ & 30 & 2.3667 & .80872 \\
\hline \multirow[t]{2}{*}{ Adventure } & Male & 52 & 3.1346 & 1.06695 \\
\hline & $\overline{\text { Female }}$ & 30 & 3.2333 & 1.19434 \\
\hline \multirow[t]{2}{*}{ Pleasure } & Male & 52 & 2.3654 & -.498 \\
\hline & $\overline{\text { Female }}$ & 30 & 2.5000 & .86103 \\
\hline Beauty & Male & 52 & 2.5577 & .97846 \\
\hline
\end{tabular}




\begin{tabular}{lllll}
\hline & Female & 30 & 2.5000 & 1.10641 \\
\hline Convenience & Male & 52 & 1.6346 & .68682 \\
\cline { 2 - 5 } & Female & 30 & 1.7667 & .67891 \\
\hline Health & Male & 52 & 2.1731 & 1.04264 \\
\cline { 2 - 5 } & Female & 30 & 2.5000 & 1.04221 \\
\hline Cheapness & Male & 52 & 2.6731 & 1.09761 \\
\cline { 2 - 5 } & Female & 30 & 2.9000 & 1.18467 \\
\hline Safety & Fale & 52 & 2.5962 & 1.05272 \\
\hline Fremale & 30 & 2.9667 & .85029 \\
\hline Male & 52 & 2.8654 & 1.08517 \\
\cline { 2 - 5 } & Female & 30 & 3.0333 & 1.12903 \\
\hline
\end{tabular}

95\% Confidence Interval of the Difference

T-tests were conducted on independent samples, the results of which are shown in Table 4. According to Cohen (1988), If the value in the significant (2-tailed) is equal or less than .05 , then there is a significant difference in the mean score and if the value is higher than .05 there is no significant difference between the two groups. In this study, as the significant value is higher than .05 , so there are no significant differences between males and females in the case of both advertising appeal. It indicates that both male and female are influenced the same whether the advertising positioning is rational or emotional.

4.3.5 Comparison in Between Age, Profession, and Education

Table 5. Comparison in-between age, profession, and education

\begin{tabular}{|c|c|c|c|c|c|c|c|c|c|c|}
\hline & \multicolumn{3}{|c|}{ Age(Years) } & \multicolumn{4}{|c|}{ Profession } & \multicolumn{3}{|c|}{ Education } \\
\hline & $\begin{array}{l}\text { Less } \\
\text { than } \\
30\end{array}$ & $\begin{array}{l}30-4 \\
5\end{array}$ & $\begin{array}{l}\text { More } \\
\text { than } \\
45\end{array}$ & $\begin{array}{l}\text { Service } \\
\text { holder }\end{array}$ & $\begin{array}{l}\text { Busine } \\
\text { ss man }\end{array}$ & $\begin{array}{l}\text { House } \\
\text { wife }\end{array}$ & Student & HSC & Bachelor & Masters \\
\hline \multicolumn{11}{|c|}{ Emotional Appeal } \\
\hline Sociality & 1.53 & 1.75 & 2.20 & 1.74 & 1.90 & 1.64 & 1.37 & 1.80 & 1.54 & 1.77 \\
\hline Relaxation & 2.82 & 2.85 & 2.20 & 2.68 & 3.40 & 2.78 & 2.87 & 3.00 & 2.87 & 2.75 \\
\hline $\begin{array}{l}\text { Family } \\
\text { Intimacy }\end{array}$ & 2.14 & 2.44 & 2.80 & 2.44 & 2.20 & 2.35 & 2.12 & 2.80 & 2.29 & 2.35 \\
\hline Adventure & 3.46 & 3.06 & 2.60 & 3.04 & 3.00 & 3.42 & 3.75 & 3.60 & 3.41 & 3.01 \\
\hline Pleasure & 2.71 & 2.20 & 2.80 & 2.38 & 2.30 & 2.42 & 2.75 & 2.20 & 2.50 & 2.39 \\
\hline Beauty & 2.64 & 2.46 & 2.60 & 2.34 & 3.00 & 2.71 & 2.87 & 3.60 & 2.54 & 2.43 \\
\hline \multicolumn{11}{|c|}{ Rational Appeal } \\
\hline Convenience & 1.82 & 1.61 & 1.60 & 1.72 & 1.50 & 1.71 & 1.62 & 1.60 & 1.58 & 1.73 \\
\hline Effectiveness & 2.39 & 2.18 & 2.80 & 2.34 & 2.00 & 2.50 & 2.00 & 2.40 & 2.54 & 2.16 \\
\hline Health & 2.89 & 2.73 & 2.20 & 2.68 & 2.70 & 2.78 & 3.25 & 2.80 & 2.75 & 2.75 \\
\hline Cheapness & 2.85 & 2.65 & 2.80 & 2.60 & 2.70 & 3.14 & 2.87 & 3.20 & 2.70 & 2.69 \\
\hline Safety & 3.03 & 2.89 & 2.60 & 2.88 & 2.90 & 2.85 & 3.37 & 3.00 & 2.79 & 2.98 \\
\hline Productivity & 3.42 & 2.97 & 2.80 & 2.96 & 3.30 & 3.42 & 3.37 & 3.80 & 3.25 & 3.00 \\
\hline
\end{tabular}


From the above table, we see that in emotional appeal all types of age groups, professionals and educational levels are influenced more by the advertisement that depicts sociality. On the other hand, in rational positioning, all are influenced more on that advertisement that demonstrating the product uses, benefits and features.

We also see from the age group that 'less than 30 years of age' people are more influenced by emotional than rational appeals and in profession 'students' are influenced more by emotional appeals than from rational.

In respect of a group of age, profession, and education most of the respondents are not influenced by those emotional appeals that demonstrated adventure related ad and in rational positioning, they are not influenced by that advertising that shows the productivity of the products.

\section{Conclusion}

This study was intended to establish how customers' purchasing decisions were influenced by advertising appeals. The investigation of research literature has demonstrated how advertising appeals are usually classified as emotional and rational, with the ability to impact consumer reaction in various ways, both mental and rational advertising appeals. Many types of research on advertising are carried out with the aim of determining the most efficient advertising appeal, however, there is no agreement among researchers as to which advertising appeal is the most attractive to consumers, and which advertising appeal is the most effective for a certain category of product.

The results of this study improve our knowledge of the impact of advertising appeals on internet purchases via social media. The assessment of the study findings shows that there are no important variations in both demands for both men and women. In the emotional appeals age group of 'below 30 years' and 'student' is reported a higher mean score than rational appeals. The advertisement depicts 'sociality' are influenced more in emotional positioning and in rational positioning 'product uses, benefits and features' related advertisement influenced more the customers.

As this paper is based on chattogram city only and one social media that is Facebook has been used in this research, so somewhat it may not portray the real scenario. So the researchers and the practitioners have a great opportunity to do further work with this issue by taking many more social sites and with the different cultures and regions as well. An advertiser must understand which appeals will have a greater impact on what kind of advertising, and it is essential that efficient promotional strategies are determined. The impact of appeal on the basis of cultural principles and the right approach can be examined by aggressive and successful international advertising agencies for goods and services. Managers can then develop strategies specifically designed for the target segments that help to boost the appeal and performance of advertising incentives.

\section{References}

Agnihotri, R., Kothandaraman, P., Kashyap, R., \& Singh, R. (2012). Bringing "social" into sales: The impact of salespeople's social media use on service behaviors and value creation. Journal of Personal Selling \& Sales Management, 32(3), 333-348. https://doi.org/10.2753/PSS0885-3134320304

Albers-Miller, N. D., \& Royne Stafford, M. (1999). An international analysis of emotional and rational appeals in services vs goods advertising. Journal of Consumer Marketing, 16(1), 42-57. https://doi.org/10.1108/07363769910250769

Ali, H. (2011). Exchanging value within individuals' networks: Social support implications for health marketers. Journal of Marketing Management, 27(3-4), 316-335. https://doi.org/10.1080/0267257X.2011.547075

Armstrong, J. S. (2010). Persuasive advertising: Evidence-based principles. Palgrave Macmillan. https://doi.org/10.1057/9780230285804

Ballantine, P. W., \& Stephenson, R. J. (2011). Help me, I'm fat! Social support in online weight loss networks. Journal of Consumer Behaviour, 10(6), 332-337. https://doi.org/10.1002/cb.374

Belch, G. E., \& Belch, M. A. (2004). Advertising and promotion: An integrated marketing communications perspective 6th. New York: NY: McGraw-Hill.

Belch, G. E., \& Belch, M. A. (2012). Advertising and promotion: An integrated marketing communications perspective 9th. New York: NY: McGraw-Hill.

Chen, Y., Fay, S., \& Wang, Q. (2011). The role of marketing in social media: How online consumer reviews evolve. Journal of Interactive Marketing, 25(2), 85-94. https://doi.org/10.1016/j.intmar.2011.01.003

Cohen, J. (1988). Statistical power analysis for the behavioral sciences. Hillsdale, NJ: Erlbaum. 
De Vries, L., Gensler, S., \& Leeflang, P. S. (2012). Popularity of brand posts on brand fan pages: An investigation of the effects of social media marketing. Journal of Interactive Marketing, 26(2), 83-91. https://doi.org/10.1016/j.intmar.2012.01.003

Gruzd, A., Wellman, B., \& Takhteyev, Y. (2011). Imagining Twitter as an imagined community. American Behavioral Scientist, 55(10), 1294-1318. https://doi.org/10.1177/0002764211409378

Hair, J. F., Black, W. C., Babin, B. J., Anderson, R. E., \& Tatham, R. L. (2009). Análisemultivariada de dados. Bookman Editora.

Hoyer, W. D., MacInnis, D. J., \& Pieters, R. (2001). Consumer behavior. Boston, Houghton Mifflin Company.

Johar, J. S., \& Sirgy, M. J. (1991). Value-expressive versus utilitarian advertising appeals: When and why to use which appeal. Journal of Advertising, 20(3), 23-33. https://doi.org/10.1080/00913367.1991.10673345

Kazmi, S. H. H., \& Batra, S. K. (2009). Advertising and Sales Promotion. Excel Books India.

Keshari, P., \& Jain, S. (2014). Consumer Response to Advertising Appeals: A Gender Based Study. Journal of Marketing \& Communication, 9(3).

Khanna, P. (2016). A Content Analysis of Emotional and Rational Appeals in Selected Products Advertising. International Journal of Management \& Social Sciences, 4(3), 568-578.

Kotler, P. (1997). Marketing Management Analysis, Planning, Implementation and Control. Practice Hall International. Inc. Upper Saddle River, New Jersey.

Kotler, P., \& Armstrong, G. (2012). Principles of Marketing. New Jersey.

Kotler, P., \& Keller, K. L. (2003). Marketing management (11th ed). Upper Saddle River NJ.

Kotler, P. (2007). Marketing management analysis, planning, implementation and control (2nd ed.). London: Prentice-Hall International.

Lantos, G. P. (2015). Consumer behavior in action: Real-life applications for marketing managers. Routledge. https://doi.org/10.4324/9781315705439

Latif, A., \& Abideen, Z. U. (2011). Effects of television advertising on children: A Pakistani perspective. European Journal of Economics, Finance and Administrative Sciences, 30(4), 38.

Li, H., Li, A., \& Zhao, S. (2009). Internet advertising strategy of multinationals in China: a cross-cultural analysis. International Journal of Advertising, 28(1), 125-146. https://doi.org/10.2501/S0265048709090441

Liang, T. P., \& Turban, E. (2011). Introduction to the special issue social commerce: a research framework for social commerce. International Journal of Electronic Commerce, 16(2), 5-14. https://doi.org/10.2753/JEC1086-4415160201

Lu, H. P., \& Hsiao, K. L. (2010). The influence of extro/introversion on the intention to pay for social networking sites. Information \& Management, 47(3), 150-157. https://doi.org/10.1016/j.im.2010.01.003

Lu, Y., Zhao, L., \& Wang, B. (2010). From virtual community members to C2C e-commerce buyers: Trust in virtual communities and its effect on consumers' purchase intention. Electronic Commerce Research and Applications, 9(4), 346-360. https://doi.org/10.1016/j.elerap.2009.07.003

Moriarty, S. E. (1991). Creative advertising: Theory and practice. Prentice-Hall.

Niazi, M. A. K., Ghani, U., \& Aziz, S. (2012). The Emotionally Charged Advertisement and Their Influence on Consumers' attitudes. International Journal of Business and Social Science, 3(1).

Panda, T. K., Panda, T. K., \& Mishra, K. (2013). Does emotional appeal work in advertising? The rationality behind using emotional appeal to create favorable brand attitude. IUP Journal of Brand Management, 10(2), 7.

Rizwan, M., Pirzada, S., Sohail, A., Nadeem, M., \& Murid, W. (2013). The Role of advertising appeals, role of celebrity \& expert in TV advertising attitude. IOSR Journal of Business and Management, 52-57.

Roozen, I., \& Claeys, C. (2009). Are We Aware of Product Placements in Music Videos?.

Sadeghi, M., Fakharyan, M., Dadkhah, R., Khodadadian, M. R., Vosta, S. N., \& Jafari, M. (2015). Investigating the effect of rational and emotional advertising appeals of HamraheAval mobile operator on attitude towards advertising and brand attitude (case study: student users of mobile in the area of Tehran). International Journal of Asian Social Science, 5(4), 233-244. https://doi.org/10.18488/journal.1/2015.5.4/1.4.233.244 
Sharma, S., \& Singh, R. (2006). Advertising: Planning and implementation. PHI Learning Pvt. Ltd.

Solomon, M. R. (1992). Customer behavior. Boston: Allyn e Bacon.

Stafford, M. R. (2005). International services advertising (ISA): defining the domain and reviewing the literature. Journal of Advertising, 34(1), 65-86. https://doi.org/10.1080/00913367.2005.10639184

Taskiran, N. O., \& Yilmaz, R. (2015). Handbook of research on effective advertising strategies in the social media age. Business Science Reference. https://doi.org/10.4018/978-1-4666-8125-5

Verma, S. (2009). Do all advertising appeals influence consumer purchase decision: An exploratory study. Global Business Review, 10(1), 33-43. https://doi.org/10.1177/097215090801000102

Wang, W., \& Benbasat, I. (2008). Attributions of trust in decision support technologies: A study of recommendation agents for e-commerce. Journal of Management Information Systems, 24(4), 249-273. https://doi.org/10.2753/MIS0742-1222240410

Wang, W., Qiu, L., Kim, D., \& Benbasat, I. (2016). Effects of rational and social appeals of online recommendation agents on cognition-and affect-based trust. Decision Support Systems, 86, 48-60. https://doi.org/10.1016/j.dss.2016.03.007

Xie, T., Donthu, N., Lohtia, R., \& Osmonbekov, T. (2004). Emotional appeal and incentive offering in banner advertisements. Journal of Interactive Advertising, 4(2), https://doi.org/10.1080/15252019.2004.10722085

Yu, T. T. (2013). Marketing communication strategy innovation based on social media reputation. Journalism University, (3), 115-120.

Zhang, H., Sun, J., Liu, F., \& G. Knight, J. (2014). Be rational or be emotional: advertising appeals, service types and consumer responses. European Journal of Marketing, 48(11/12), 2105-2126. https://doi.org/10.1108/EJM-10-2012-0613 